\title{
総合健診におけるタクシー乗務員の健康管理について
}

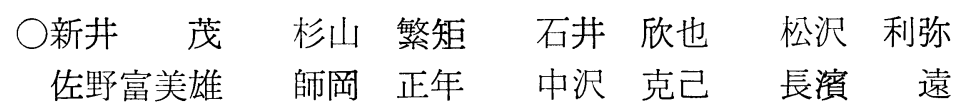

タクシー乗務員の健康管理について, 総合健診等の成 績を分析し，今後の保健指導の指標を得ることを試みた。 全体的にタクシー乗務員は肥満傾向の者が多く, 肥満 度 $+10 \%$ 以上が $38.1 \%$ 之約 4 割に達する。また, 肥満 度 $+20 \%$ 以上に限った場合であ $14.9 \%$ 之高率である。

年踰構成も偏向があり，40 歳代〜50 歳代に集中した 年齢構成になっている。また, 平均年齢む 46.9 歳と高 い。

肥満が健康にどのような影響を及ぼすのか，総合健彰 等の成績で異常所見出現率を肥満度別に調査分析し, 次 のような結果を得た。肥満群では「血圧」「糖尿病」「血 液脂質」「肝機能」「痛風 (尿酸)」「眼底」等の検查で有 意に異常所見出現率が高率となり, 肥満がこれらの疾患 のリスクファクターの一つであると考えられる。

また，瘦せ過ぎの群では「胸部X線」「胃部X線」「肺 機能」「糖尿病」等の検査を高率であった。

次に, 問獄データを異常所見群之正常群に分け, 暂 好, 生活, 自覚症状等について調査分析した。その結 果, 有意に異常所見群に多く認められたのは次に挙げる 事項である。

生活, 嗜好の調査では，「外食が多い」「好き嫌いが多 い」「運動しない」「アルコールをよく飲む」「タバコを 吸う」「清涼飲料類をよく飲む」「野菜の摄取が少ない」 「肉類の摄取が多い」「食事間隔が不定である」「満腹ま で食べる」「塩分の摄取量が多い」等であった。

また, 異常所見群に多く認めた自覚症状は次の事項で ある。「太ってきた」「瘐せてきた」「吐き気があする」 「便秘，下浰しやすい」「のどがかわく」「食欲がない」 「吐き気がする」「目がかすむ，疲れる」「息切れ動悸が
ある」「手足がしびれる」「咳や痰がでる」「耳鳴りがす る」「胃が重い, 痛む」「腰, 関節背中が痛む」等で，各 々疾患ごとに特徵的な自覚症状が推察される結果を得 た。

以上のととから,タクシー乗務員は外食の機会が多 く，外食については自分の嗜好にあった食品しか食べな い，肉類中心で野菜の摄取が不足ぎみになる，塩分の摄 り過ぎをきたす等があげられる。また，食事間隔が一定 しない，勤務時間内外に清涼飲料等をよく飲むととが多 く, 結果として食事のバランスを欠いたり生活のリズム を崩す結果となり, 肥満や健康状態の悪化を招くことが 推察される。

余餟の利用状態についてあ，不足ぎみの睡眠を補うこ とや，習慣的にアルコール類を飲むととに費やされ，運 動やレクレーション等が不足しているようである。運動 については，全くしないと回答した率は $79.8 \%$ と全体 の 8 割弱に達し，習慣的に運動をしている者は，わずか $4.3 \%$ でしかなかった。しかし, 異常所見群と正常所見 群の間に運動については有意な差は認められなかった。 これについては，習慣的に運動をしている比率が全体的 に低いことが作用していると考えられる。

今後の指導の在り方としては, 勤務形体により避ける ことのできない外食について，一品物ではなく栄養バう ンスのとれた定食等を選び上手に食事を摂るよう心掛け るとと，塩分を控えることできるだけ野菜を摂る等の徹 底をはかる。

また，運動する機会を各自積極的につくるととや，ス トレスを蓄積しないようレクレーション等で余暇を充実 させるととが望まれる。

\section{A Studies on Health Care of the Taxi Driver in AMHTS \\ 東京自動車連合健康保険組合 柳橋病院}

